\title{
The Possible Therapeutic Effect of Rebamipide and Stem Cell Derivative Microvesicles on Experimentally Provoked Colitis in Rats: Histological and Immuno Hisochemical Study
} Original Article

\author{
Omayma K. Helal, Aisha EL. Mansy, Ola M. Mohamed and Hala El. Ahmed Radwan
}

Department of Histology and Cell Biology, Faculty of Medicine, Benha University

\begin{abstract}
Background Ulcerative colitis (UC) is a chronic inflammatory disorder. Clinically, there are periods of pain in abdomen and bloody diarrhea. The used medication induce clinical diminution, but with many difficulties.

Aim of the study Evaluation the beneficial outcomes of rebamipide and microvesicles come from mesenchymal stem cells on treatment of induced colitis.

Material and methods Fifty adult male albino rats were divided into 5 groups. Group I was the control group. Group II rats received intra-colonic instillation of $1 \mathrm{ml} / \mathrm{rat} / \mathrm{day}$ of $5 \%$ acetic acid $(5 \% \mathrm{v} / \mathrm{v})$ for 3 sequential days. Group III Rats were received a suspension of (1\% rebamipide and $1.5 \%$ carboxy-methyl cellulose), intra-colonic in a dose $1 \mathrm{~mL} / \mathrm{kg} /$ day after provocation of colitis for 14 days. Group IV rats were given out a single dose of $15 \mu \mathrm{g}$ of microvesicles dissolved in $0.5 \mathrm{ml}$ of phosphate buffered solution (PBS) delivered intravenous in caudal vein after provocation of colitis. Group V rats were given microvesicles and Rebamipide as Group ПI and Group IV after provocation of colitis. The colon sections were managed and examined using histological and immunohistochemical study.

Results Group II showed patchy ulceration with loss of surface epithlium and under-lying connective tissue. There is infiltration of mononuclear cells and congested blood vessels in lamina propria and sub mucosa. Group III showed near-normal mucosa with surface columnar cell and goblet cells in some areas with discontinuity in certain areas. Group IV showed almost intact mucosa. Group V showed intact mucosa with surface absorptive cells and goblet cells close to control group.

Conclusion: Each of rebamipide and microvesicle improved the prompted ulcerative colitis, but their combination was more effective.
\end{abstract}

Received: 13 March 2019, Accepted: 26 March 2019

Key Words: Colon, microvesicles, rebamipide, ulcerative.

Corresponding Author: Hala El. Ahmed Radwan, MSc, Histology and Cell Biology, Faculty of Medicine, Benha Univeristy, Egypt, Tel.: +20 1127708990, E-mail: halaradwan011@gmail.com

ISSN: 1110-0559, Vol. 42, No. 3

\section{INTRODUCTION}

Ulcerative colitis (UC) is accompanied by occasions of abrupt reductions and exacerbations of inflammation. UC distress the rectum and different areas of the proximal colon $^{[1]}$. Colonic mucosa exhibits inflammation, ulceration. So, the patient complain of bloody diarrhea, abdominal spasms and weight loss ${ }^{[2]}$. The inflammatory procedure is accompanied by inflammatory cells infiltration in the mucosa and sub mucosa and increased production of mediators of inflammation [(tumor necrosis factor $\alpha$ (TNF- $\alpha$ ), interleukin (IL) $1 \beta$, IL- 6 , IL-17, and IL21 and reactive oxygen species (ROS) $]^{[3]}$. The treatment focuses on managing inflammation and inhibiting disease progress and involves systemic and topical steroid, 5-aminosalicylate compounds, and immunosuppressive agents ${ }^{[4]}$. Additionally, clinical trials are currently assessing the application of stem cell transplantation in UC and bone marrow transplantation has been used ${ }^{[5,6]}$.
Rebamipide \{2- (4chlorobenzoylamino)-3 [2-(1H) quinolinon4yl] propionic acid $\}$, is a cytoprotective vehicle that enhance epithelial renewal, control inflammation and free radicals deposition ${ }^{[7]}$. Rebamipide has an effectual role in modification of proteins that form the tight junction of mucosal cells so, preserve the integrity of the mucosa ${ }^{[8,9]}$. The imbalance that appears between T helper 17 (h17) /T regulatory cell in UC is adjusted by rebamipide ${ }^{[10-12]}$.

Stem cells represent a possible approach for tissue restore and redevelopment. Mesenchymal stem cells (MSCs) are multi-potent and self-renewing cells, that present in all post natal organs ${ }^{[13]}$. Bone marrow originated mesenchymal stem cells (BMSCs) have capacity to heal induced mucosal colonic injury in rats ${ }^{[14]}$. BMSCs secrete microvesicles (MVs) that play a significant role in repair and differentiation of impaired tissue ${ }^{[15]}$. The content of MVs indicates the cell of origin. So, if microvesicles were isolated from MSCs, they carry their character. 
Microvesicles are composed of membrane fragments surrounding bioactive lipids, cytoplasmic proteins and nucleic acids ${ }^{[16]}$. So, Microvesicles discharged by BMSCs afford a new supplier and a great potential donor for regenerative medicine, Reestablishing normal structure and function of injured tissue, through the capability of MVs to deliver molecules that improve cell division ${ }^{[17]}$.

\section{MATERIALS AND METHODS}

\section{Reagents}

Acetic acid: (El-Naser Pharmaceutical Chemicals Company, Egypt) $5 \%$ acetic acid ${ }^{[18,19]}$.

Rebamipide: (Otsuka Pharmaceutical Co. Ltd., Tokyo, Japan) a suspension of 1\% Rebamipide in $1.5 \%$ carboxymethylcellulose (1gm of rebamipide and $1.5 \mathrm{gm}$ of carboxymethylcellulose in $97.5 \mathrm{ml}$ water) (Dai-Ichi Chemical Industries, Tokyo, Japan) in water. This enema suspensions were dispensed per rectum in a volume of 1 $\mathrm{mL} / \mathrm{kg}$ body weight in the morning for 14 days $^{[20]}$.

Mesenchymal stem cells derived microvesicles: They were prepared in Biochemistry Departments, Kasr Al-Ainy Faculty of Medicine, from BM-derived MSCs through conditioned medium by ultracentrifugation. Each animal was given a single dose of $15 \mu \mathrm{g}$ of MVs dissolved in 0.5 $\mathrm{ml}$ of phosphate buffered solution (PBS) intravenously in caudal vein ${ }^{[21]}$.

\section{Animals}

This study was done on 50 adult male albino rats, with an average weight of $180-200$ grams. Animals were settled in the animal research laboratory unit of Kasr Al-Ainy Faculty of Medicine, Cairo University. Firm nursing and cleaning procedures were employed to keep the animal in a typical well condition, the animals were settled in animal coop at room temperature $\left(25 \pm 1^{\circ} \mathrm{C}\right)$, relative humidity $(55 \pm 5)$ with $12 \mathrm{~h}$ light/12h dark cycle, fed standard basal diet and water. Rats were acclimated to these conditions for two weeks before beginning the experiment. All morals rules for animal management were monitored. The experimental protocol was advised by the Institutional Animal Care Committee.

\section{Experimental procedure}

(1) Group I (the control group): was divided into 2 sub-groups:

Group I a: Rats received a suspension of $1.5 \%$ carboxymethyl-cellulose in a volume of $1 \mathrm{~mL} / \mathrm{kg} /$ day body weight in the morning for 14 days, using soft pediatric catheter of external diameter $2 \mathrm{~mm}$. Catheter was lubricated with gel inserted for a distance of $8 \mathrm{~cm}$.

Group I b: Rats received $0.5 \mathrm{ml}$ of phosphate buffered solution (PBS) delivered intravenously in caudal vein.

(2) Group II (UC group): 10 rats received 5\% acetic acid by intra-colonic instillation of $1 \mathrm{ml} / \mathrm{rat} /$ day $\mathrm{mL} / \mathrm{kg} 3$ subsequent days, using soft pediatric catheter of external diameter $2 \mathrm{~mm}$, colon $8 \mathrm{~cm}$ proximal to anal opening, sustained in a supine Trendelenburg position for $30 \mathrm{~s}$ to avoid outflow of the intracolonic instillation.

(3) Group III (UC with Rebamipide): 10 rats received $1 \mathrm{~mL}$ of (an enema suspension of $1 \%$ Rebamipide in $1.5 \%$ carboxymethylcellulose) $/ \mathrm{kg}$ body weight intra-colonic in the morning, $8 \mathrm{~cm}$ proximal to anal opening at the 4 th day after acetic acid injection.

(4) Group IV (UC with MVs): 10 rats received microvesicles by intravenous route at the 4 th day after acetic acid injection.

(5) Group V (UC with MVs and Rebamipide): 10 rats received rebamipide and microvesicles as Group $\Pi I$ and Group IV after induction of ulceration.

\section{Induction of ulcerative colitis}

Colitis was produced according to the process illustrated by some authors ${ }^{[18,19]}$. Rats were retained under thiopental anesthesia $(50 \mathrm{mg} / \mathrm{kg}$; given out by intra-peritoneal (ip) injection) after a 24-h fast, and a 2.7-mm-diameter soft pediatric catheter was lubricated with gel and then inserted $8 \mathrm{~cm}$ proximal to the anus. A solution of $1 \mathrm{ml} / \mathrm{rat} / \mathrm{day}$ of acetic acid $(5 \% \mathrm{v} / \mathrm{v})$ was instilled into the colon and continued in a supine Trendelenburg position for $30 \mathrm{~s}$ to evade outflow of the intracolonic instillation.

\section{Light microscopic studies}

The fasted rats were anesthetized with ether and sacrificed by means of cervical decapitation. Rats in group II were sacrificed at $4^{\text {th }}$ day after intrarectal injection of acetic acid (induction of UC). Rats in other groups were sacrificed 2 weeks after generation of UC. The abdominal cavities were rapidly opened and the distal colon was removed. The specimens were fixed in $10 \%$ buffered formal saline and managed for paraffin sections of 5-7 $\mu \mathrm{m}$ thickness, and fixed on glass slides for H\&E, and alcian blue $\operatorname{stain}^{[22]}$. Other portions were affixed on positively charged slides for immunohistochemical study using avidin biotin immunohistochemical staining for TNF- $\alpha$ And PCNA reaction ${ }^{[23]}$.

\section{Immunohistochemical staining for tumor necrosis factor $\alpha$}

Immunohistochemical detection of TNF- $\alpha$ in the cells of the colon was carried out by means of standard avidin-biotin-peroxidase complex system as per the instructions on the kit used (Dako, Glostrup, Denmark). Monoclonal mouse anti-human antibody was used as the primary antibody against TNF- $\alpha$. Sections were fixed on positively charged glass slides. The paraffin sections were dep- araffinized, hydrated, and preserved in $10 \% \mathrm{H}_{2} \mathrm{O}_{2}$ to block endogenous peroxidase activity, and the slides were rinsed in running water and PBS. The primary specific antibody was diluted 1: 300 with PBS. The slides were incubated with primary antibody in a chamber at $4^{\circ} \mathrm{C}$ After incubation, they were rinsed three times in PBS and 
incubated for 30 min at $37^{\circ} \mathrm{C}$ with the biotinylated secondary antibody diluted $1: 500$ with PBS $+0.1 \%$ saponin. The site of antibody immunostaining was visualized after incubation with the avidin-biotin-peroxidase complex (ABC reagent) for $30 \mathrm{~min}$ and afterwashing with PBS. Freshly prepared diaminobenzidine was used as chromogen. The sections were incubated with diaminobenzidine for $10 \mathrm{~min}$ and then washed with tap water, counterstained with hematoxylin, dehydrated, and mounted. For negative control, the primary antibody was replaced with PBS (phosphate buffered solution $)^{[23]}$.

\section{Immunohistochemical staining of PCNA}

PCNA protein in the sections of the colon was limited by a standard immunohistochemicalmethod. Briefly, after deparaffinization and rehydration, buffered-formalinfixed sections were treated with $3 \% \mathrm{H}_{2} \mathrm{O}_{2}$ for $30 \mathrm{~min}$ at room temperature to quench endogenous peroxidase. The sections were washed with trisbuffered saline (TBS) having $0.1 \%$ Tween 20 (TBS-T) for $5 \times 10 \mathrm{~min}$, then blocked with $5 \%$ normal goat serum for $1 \mathrm{~h}$ at room temperature. After again washing with TBS-T for $5 \times 10 \mathrm{~min}$, the sections were incubated with 1:50 dilution of primary antibody rabbit polyclonal anti-PCNA (Millipore, Billerica, MA, USA) (AbcamInc., Cambridge, MA, USA) overnight at $4 \mathrm{C}$. The immune complexes of antigens with primary antibodies on the tissue section were noticed by using the secondary antibody anti-rabbit immunoglobulinG (IgG) conjugatedwith biotin and were visualized with the use of a 3,3-diaminobenzidine peroxidase substrate kit (Vector Labs,Burlington, Canada). The negative staining control were the sections incubated with normal rabbit $\operatorname{IgG}$ as a primary antibody or without the primary antibody ${ }^{[23]}$.

\section{Preparation of microvesicles}

MSCs cultured for $24 \mathrm{~h}$ with Dulbecco's Modified Eagle Medium (DMEM). After this time, the medium was assembled, centrifuged at $1000 \mathrm{rpm}$ for 5 minutes then at $2500 \mathrm{rpm}$ for 15 minutes and filtered through $0.45 \mu \mathrm{m}$ filter to remove the cells. The animals received $.5 \mathrm{ml}$ of a single dose of CM provided intravenously ${ }^{[24]}$. They were originated from the conditioned medium by ultracentrifugation by thermo scientific ultracentrifuge in Biochemistry Department, Kasr Al-Ainy Faculty of Medicine. The medium was ultracentrifuged at 100,000 $\mathrm{g}$ for one hour at $4^{\circ} \mathrm{C}$ to pellet microvesicles. The pellets were occupied and suspended in phosphate buffered saline (PBS) ${ }^{[25,26]}$, Microvesicles were prepared by separation of MSC from the expanding medium after centrifugation and removing the supernatant which was centrifuged and filtered several times to get the microvesicles. Microvesicles pellets were prepared for visualization by transmission electron microscope (TEM). Microvesicles pellets were gently located on Formvar-coated copper grids, allowed to adsorb for 4-5 min, and processed for standard uranyl-acetate staining. The grid was washed with three changes of PBS and allowed to semidry at room temperature before inspection by TEM $^{[24]}$ (Figure 1).

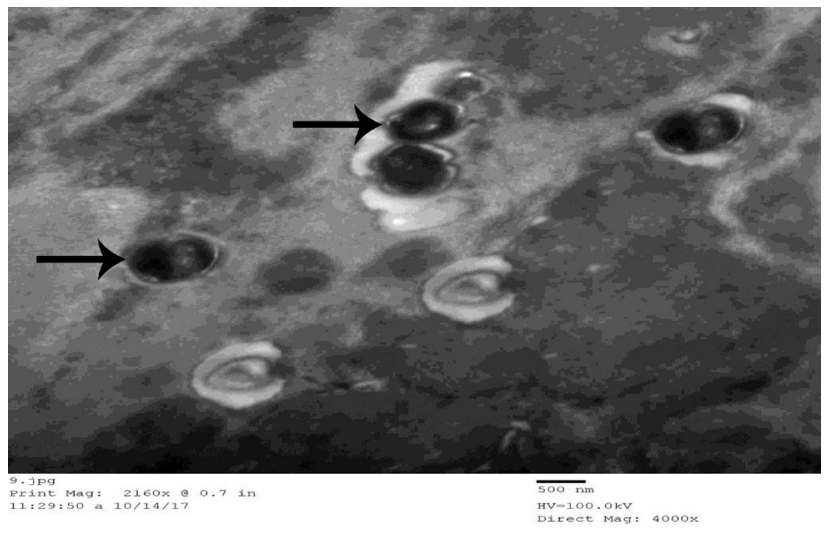

Fig. 1: A transmission electron micrograph of purified microvesicls with spheroid appearance and their size about $500 \mathrm{~nm}$ (arrows). (TEM x 4000)

\section{Morphometric and statistical study}

The mean area $\%$ of Alcian blue, TNF-Alpha reaction, and PCNA immuno-expression was quanti-fied in 5 images from 5 rats of each group using Statistical Package for Social Science software computer program version 22 (SPSS, Inc., Chicago, IL, USA). Data were presented in mean and standard deviation. One way Anal $\neg$ ysis of variance (ANOVA) with Post Hoc tukey tests were used for comparing quantitative parametric differences among the groups. The data was extracted as the mean (M) value, standard deviation (SD) and differences were believed to be sta $\neg$ tistically significant (sig) at $p<0.05$ value.

\section{RESULTS}

\section{Histological results}

\section{$H \& E$ Results}

Group I showed apparently normal mucosa with simple columnar epithelium and goblet cells. The Lamina Propria showed regular arranged closely related crypts. Also, muscularis mucosa appeared in this section (Figure 2). Group II showed showed patchy ulceration with absence of mucosa folding, loss of surface columnar epithelial lining, and distorted crypts with a few goblet cells, Lamina propria and submucosa showed heavy mononuclear cellular infiltration. There were congested blood vessels in lamina propria and submucosa (Figure 3). Group III showed discontinuity in mucosal surface in some areas with apparently normal mucosa with simple columnar epithelium and goblet cells in other areas. Lamina propria showed many apparently normal crypts with some damaged crypts. There were mononuclear cellular infiltration cell infiltration and congested blood vessels in lamina propria and submucosa (Figure 4). Group IV showed apparently intact mucosa with surface simple columnar absorptive epithelial cells and goblet cells and nearly regular organized closely related crypts Lamina propria and submucosa showed minimal mononuclear cellular infiltration. (Figure 5). Group V showed apparently intact mucosa close to control, with simple columnar epithelium and goblet cells and regularly arranged crypts in lamina propria. Sub 
mucosa and muscularis mucosa more or less close, were close to control group in their structure. (Figure 6).

\section{Alcian blue results}

Group I showed numerous alcian blue positive stained goblet cells, that formed main lining of crypts of lamina propria of colon. (Figure 7). Group II showed few alcian blue positive stained goblet cells (Figure 8). Group III showed some alcian blue positive stained goblet cells (Figure 9). Group IV showed many alcian blue positive stained goblet cells (Figure 10). Group V showed numerous alcian blue positive stained goblet cells. (Figure 11).

\section{Immunohistochemical detection of TNF- $\alpha$.}

Group I showed faint tumor necrosis factor- $\alpha$ reaction (Figure 12). Group II showed dense expression of tumor necrosis factor- $\alpha$ reaction (Figure 13). Group III showed moderate expression of tumor necrosis factor $\alpha$ (Figure 14)

Group IV showed low expression of tumor necrosis factor $\alpha$ reaction (Figure 15). Group V showed faint tumor necrosis factor $\alpha$ reaction more or less close to control (Figure 16).

\section{Immunohistochemical detection of PCNA}

Group I showed numerous PCNA immunopositive nuclei in form of dark brown stained nuclei of mucosal cells (Figure 17). Group II showed few PCNA immunopositive nuclei in the mucosal cells (Figure 18). Group III showed some PCNA immune-positive nuclei in the cells covering the mucosal surface. (Figure 19). Group IV showed many PCNA immunopositive nuclei in the mucosal cells of colon mucosa (Figure 20). Group V showed numerous PCNA immunopositive nuclei in the colon mucosa (Figure 21).

\section{Morphometric results}

Group II showed significant decrease in the mean area $\%$ of alcian blue stained goblet cells within mucosal crypts when compared with group I, significant increase in the area $\%$ of TNF- $\alpha$ reaction expression when compared to control group and significant decrease in area $\%$ of the immunopositive nuclei for PCNA reaction compared to group I.

Group III showed significant decrease in the mean area $\%$ of alcian blue +ve goblet cells when compared to control group. There was significant increase in the area $\%$ of TNF- $\alpha$ area expression when compared to control group. There was significant decrease in the area $\%$ of expression of PCNA positive cells in group III compared to group I. Group IV showed non-significant decrease in the mean $\%$ area of alcian blue + ve cells when compared to group I. there was significant increase in $\%$ area of TNF- $\alpha$ expression compared to group I. there was non-significant decrease PCNA immunopositive nuclei compared to group I. Group V showed non-significant decrease in the mean $\%$ area of alcian blue + ve goblet cells when compared with group I. The area $\%$ of TNF- $\alpha$ expression in group $\mathrm{V}$ was non significantly increased compared to group I. there was non-significant decrease in the $\%$ area of PCNA immunopositive nuclei compared to group I (Table 1,2,3 and Histogram 1,2,3).

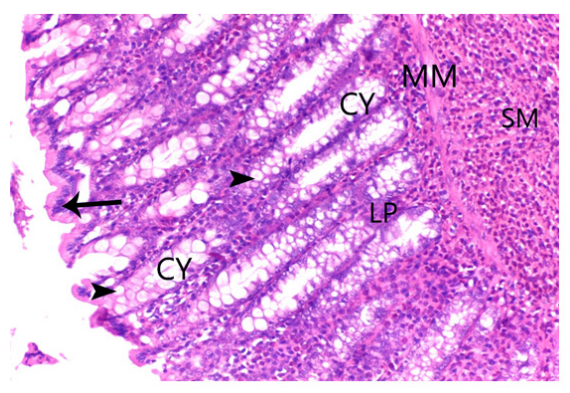

Fig. 2: A photomicrograph of a transverse section of a distal colon of group I (control) showing normal mucosa with simple columnar absorptive cells (arrow), lamina propria ( LP) with normally arranged crypts $(\mathrm{CY})$ with numerous goblet cells. There are more or less nearly normal muscularis mucosa (MM) and Submucosa (SM). (H\&E 200)

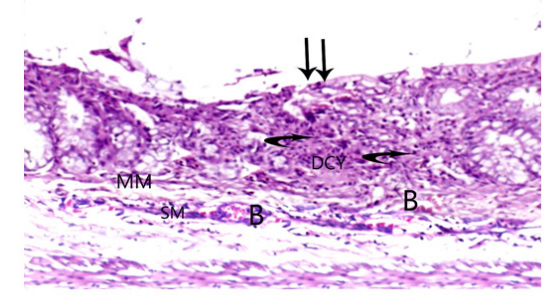

Fig. 3: A photomicrograph of a transverse section of a distal colon of group II (colitis) showing ulceration (double arrows), distorted crypts (DCY), heavy mono nuclear inflammatory cellular infiltration (curved arrows) and congested blood vessel (B). Muscularis mucosa (MM) is thin. Sub mucosa show congested blood vessels (B) and inflammatory cells infiltration. (H \& E X 200)

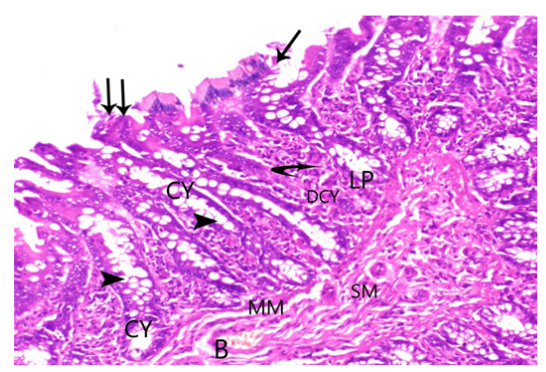

Fig. 4: A photomicrograph of a transverse section of a distal colon of Group III (UC and rebamipide) impaired mucosal surface (double arrows) and other regions of approximately normal epithelium (single arrow) and crypts (CY) with many goblet cells (arrows head). Also, there are damaged crypts (DCY) and moderate inflammatory cellular infiltration (curved arrow) in lamina propria (LP), thin muscularis mucosa (MM) and sub mucosa (SM) show congested blood vessels (B). (H\& E X 200) 


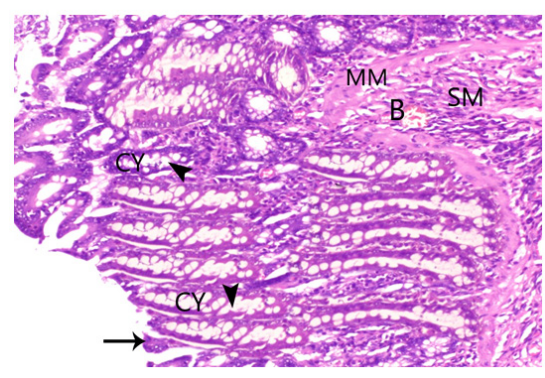

Fig. 5: A photomicrograph of a transverse section of a distal colon of Group IV (microvesicles treated group) showing more or less normal mucosal covering, with simple columnar absorptive cells (arrow) with goblet cells (arrows head). Lamina propria show normal crypts (CY) lined with many goblet cells and mild inflammatory cell infiltration in between crypts. The sub mucosa show mild mono nuclear inflammatory cell infiltration (curved arrow) and congested blood vessels (B). (H \& E X 200)

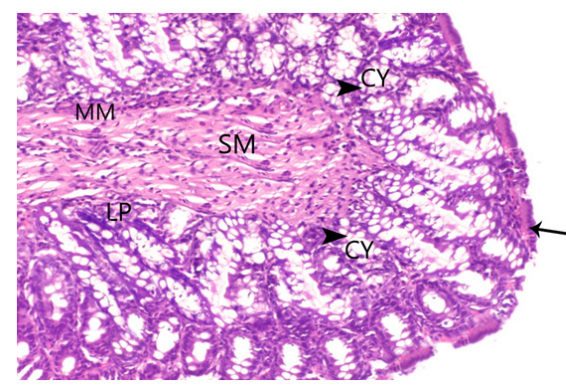

Fig. 6: A photomicrograph of a transverse section of a distal colon of group V (rebamipide and microvesicles treated group) showing nearly normal mucosa with continuous surface columnar absorptive cells (arrow) with goblet cells (head arrows). Lamina propria (LP) showing regularly arranged closely related crypts $(\mathrm{CY})$ with numerous goblet cells with absence of inflammatory cell infiltration. Muscularis mucosa (MM) with normal thickness. Submucosa (SM) shows normal connective tissue. (H \& E X 200)

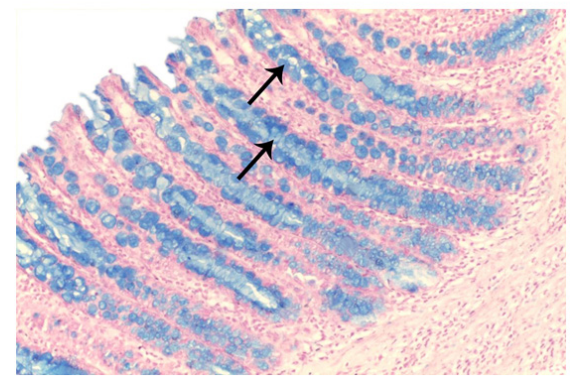

Fig. 7: A photomicrograph of a transverse section of a distal colon from group I (control) showing numerous alcian blue positive stained goblet cells in colon mucosa and crypts (arrows). (Alcian blue $\times 200$ )

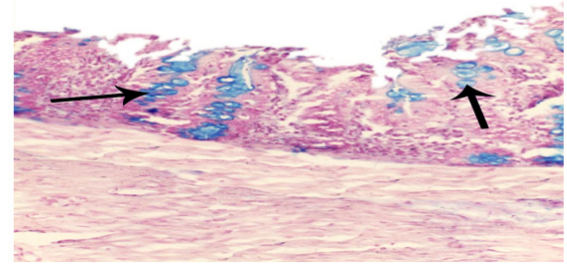

Fig. 8: A photomicrograph of a transverse section of a distal colon from group II (UC group) showing few alcian blue positive stained goblet cell in colon mucosa and crypts (arrows). (Alcian blue $\times 200$ )

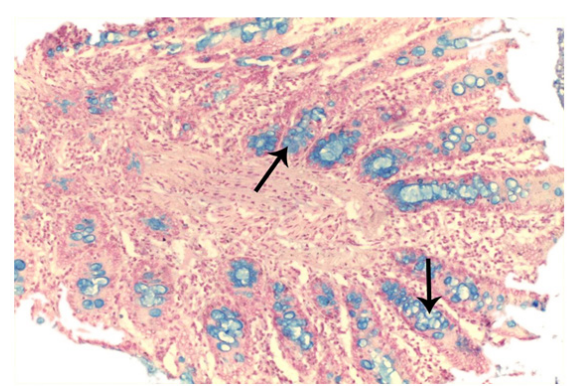

Fig. 9: A photomicrograph of a transverse section of a distal colon from group III (UC and rebamipide) showing some alcian blue positive stained goblet cells in colon mucosa and crypts (arrows). (Alcian blue $\times 200$ )

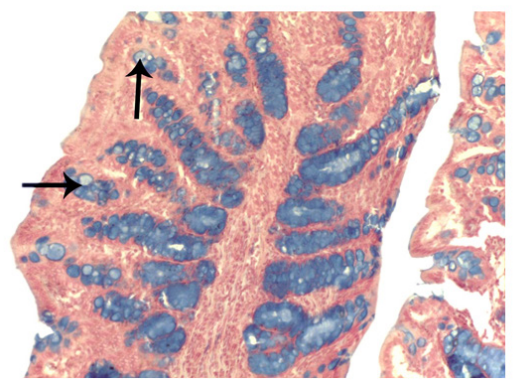

Fig. 10: A photomicrograph of a transverse section of a distal colon from group IV (UC and microvesicles) showing many alcian blue positive stained goblet cells in colon mucosa and crypts arrows). (Alcian blue $\times 200$ )

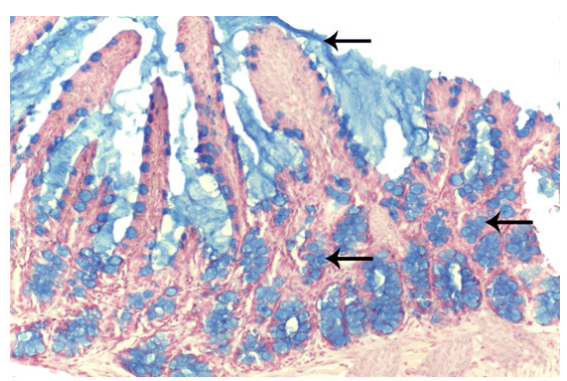

Fig. 11: A photomicrograph of a transverse section of a distal colon from group V (UC, rebamipide and microvesicles) showing numerous goblet cells in colon mucosa and crypts. (Alcian blue $\times 200$ )

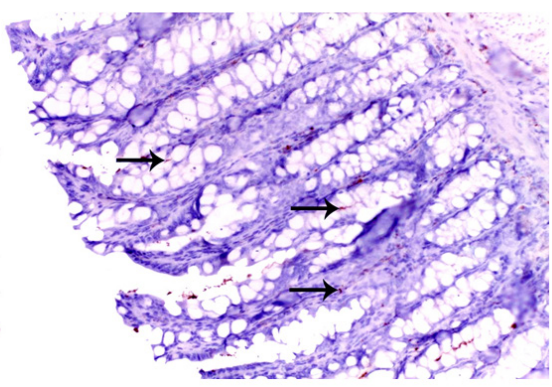

Fig. 12: A photomicrograph of a transverse section of a distal colon from group I (control group) exhibiting minimal expression of TNF- $\alpha$ reaction (arrows). (Immunohistochemistry stain for TNF- $\alpha \times 200$ ) 


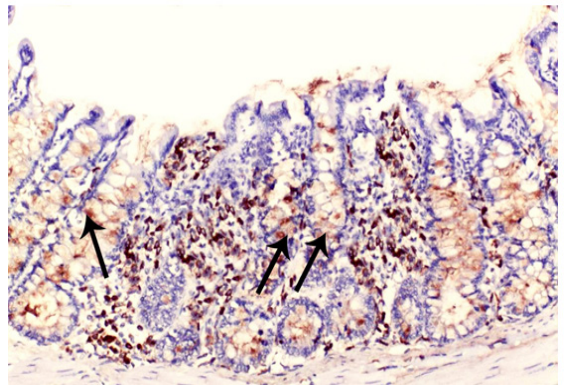

Fig.13: A photomicrograph of a transverse section of a distal colon from group II (UC) exhibiting dense expression of TNF- $\alpha$ reaction (arrows). (Immunohistochemistry stain for TNF- $\alpha \times 200$ )

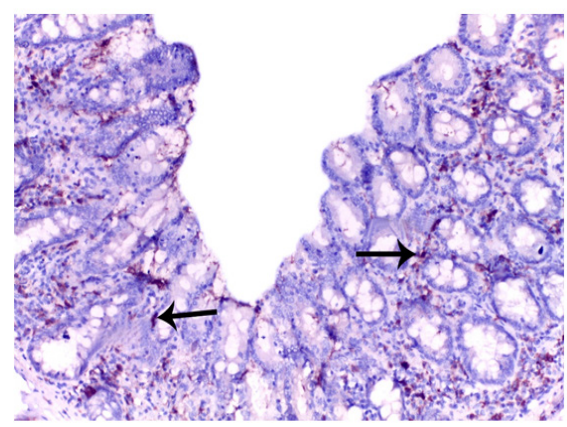

Fig. 14: A photomicrograph of a transverse section of a distal colon from group III (UC and rebamipide) showing moderate expression of TNF- $\alpha$ reaction (arrows). (Immunohistochemistry stain for TNF- $\alpha \times 200$ )

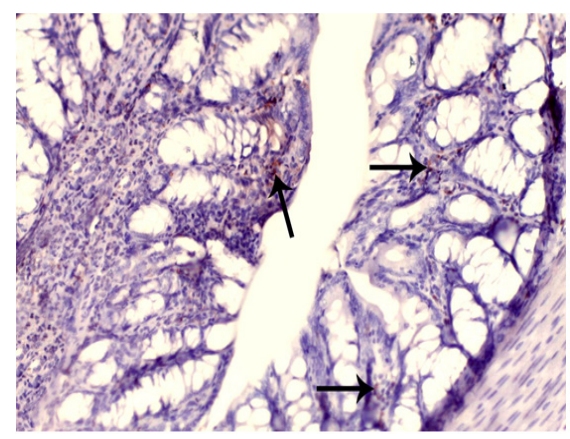

Fig. 15: A photomicrograph of a transverse section of a distal colon from group $1 \mathrm{~V}$ (UC and microvesicles) showing minimal expression of TNF- $\alpha$ reaction (arrows). (Immunohistochemistry stain for TNF- $\alpha \times 200$ )

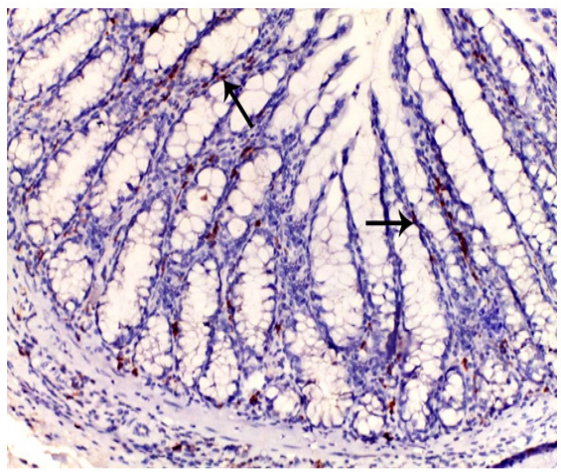

Fig. 16: A photomicrograph of a transverse section of a distal colon group $\mathrm{V}$ (UC rebamipide and microvesicles) showing minimal expression of TNF- $\alpha$ reaction. (arrows). (Immunohistochemistry stain for TNF- $\alpha$ X 200)

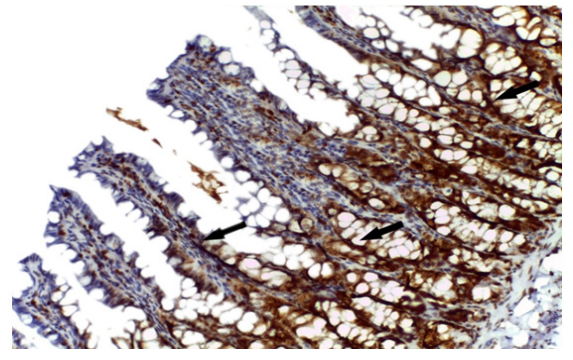

Fig. 17: A photomicrograph of a section in distal colon of a rat from group I (control group) exhibiting numerous PCNA immunopositive nuclei in the mucosal cells (arrows). (Immunohistochemistry stain for PCNA X 200)

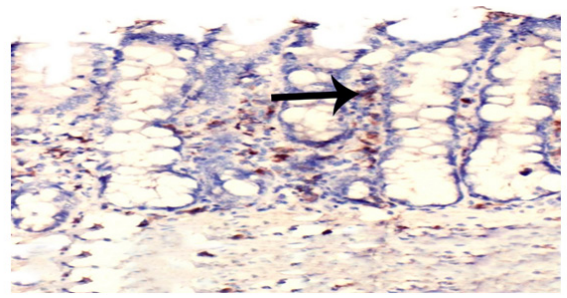

Fig. 18: A photomicrograph of a section in distal colon of a rat from group II (UC group) exhibiting few PCNA immunopositive nuclei in the mucosal cells (arrows). (Immunohistochemistry stain for PCNAX 200)

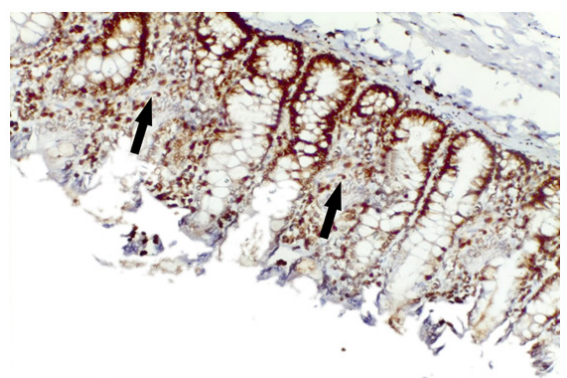

Fig. 19: A photomicrograph of a section in the distal colon of group III (UC and rebamipide) exhibiting PCNA immunopositive nuclei (arrows) (Immunohistochemistry stain for PCNA X 200)

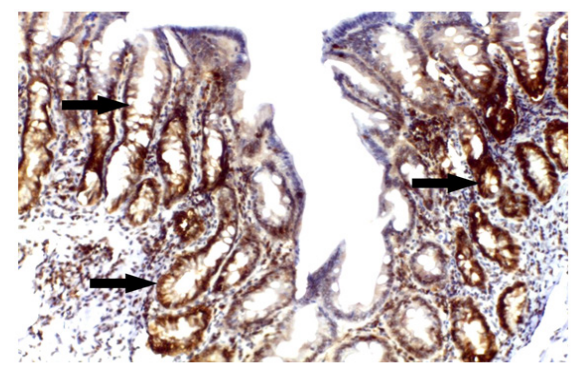

Fig. 20: A photomicrograph of a section in the colon of a rat from group $1 \mathrm{~V}$ (UC and microvesicles) exhibiting many PCNA immunopositive nuclei in the cells lining colon mucosa (arrows). (Immunohistochemistry stain for PCNA X 200)

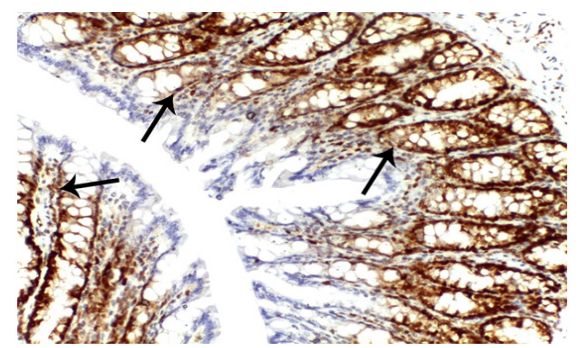

Fig. 21: A photomicrograph of a section in the colon of a rat from group V (UC, rebamipide and microvesicles) exhibiting numerous PCNA immunopositive nuclei in the cells lining colon mucosa (arrows). (Immunohistochemistry stain for PCNA X 200) 
Table 1: Showing the mean area $\%$ and SD of Alcian blue among all groups with difference between all groups by Post Hoc tukey test

\begin{tabular}{|c|c|c|c|c|c|c|c|}
\hline & & \multicolumn{6}{|c|}{ GROUPS } \\
\hline & & Group I & Group II & Group III & Group IV & Group V & $P$ \\
\hline \multirow{7}{*}{ Alcian blue } & Mean & 15.76 & 1.425 & 4.479 & 12.35 & 13.90 & $<0.001 *$ \\
\hline & $\pm \mathrm{SD}$ & 3.152 & 0.2850 & 0.8958 & 3.869 & 4.580 & \\
\hline & & & $\mathrm{P} 1=<0.001 *$ & $\mathrm{P} 1=<0.001 *$ & $\mathrm{P} 1=0.1$ & $P 1=0.65$ & \\
\hline & & & & $\mathrm{P} 2=0.01 *$ & $\mathrm{P} 2=<0.001^{*}$ & $\mathrm{P} 2=<0.001^{*}$ & \\
\hline & significance & & & & $\mathrm{P} 3=<0.001^{*}$ & $\mathrm{P} 3=<0.001 *$ & \\
\hline & & & & & & $\mathrm{P} 4=0.78$ & \\
\hline & & & A & A,B & $\mathrm{B}, \mathrm{C}$ & $\mathrm{B}, \mathrm{C}$ & \\
\hline
\end{tabular}

SD:standard deviation P:Probability $*$ :significance $<0.05$

Test used: One way ANOVA followed by post-hoc tukey

$\mathrm{A}=\mathrm{P} 1$ : significance relative to Group 1

$\mathrm{B}=\mathrm{P} 2$ : significance relative to Group 2

$\mathrm{C}=\mathrm{P} 3$ : significance relative to Group 3

$\mathrm{D}=\mathrm{P} 4$ : significance relative to Group 4

Table 2: Sh0wing the mean area $\%$ and SD of for TNF- $\alpha$ among all groups with comparison between all groups by P0st Hoc tukey test

\begin{tabular}{|c|c|c|c|c|c|c|c|}
\hline & & \multicolumn{6}{|c|}{ GROUPS } \\
\hline & & Group I & Group II & Group III & Group IV & Group V & $P$ \\
\hline \multirow{7}{*}{ TNF } & Mean & 0.0730 & 2.046 & 0.80 & 0.58 & 0.355 & $<0.001 *$ \\
\hline & $\pm \mathrm{SD}$ & 0.0146 & 0.4092 & 0.25 & 0.11 & 0.10 & \\
\hline & & & $\mathrm{P} 1=<0.001 *$ & $\mathrm{P} 1=<0.001 *$ & $\mathrm{P} 1=<0.001 *$ & $\mathrm{P} 1=0.055$ & \\
\hline & & & & $\mathrm{P} 2=<0.001 *$ & $\mathrm{P} 2=<0.001 *$ & $\mathrm{P} 2=<0.001 *$ & \\
\hline & Posthoc & & & & $\mathrm{P} 3=0.21$ & $\mathrm{P} 3=<0.001 *$ & \\
\hline & & & & & & $\mathrm{P} 4=0.17$ & \\
\hline & & & $\mathrm{A}$ & A,B & $\mathrm{A}, \mathrm{B}$ & $\mathrm{B}, \mathrm{C}$ & \\
\hline
\end{tabular}

SD :standard deviation P:Probability $*$ :significance $<0.05$

SD:standard deviation P:Probability *:significance $<0.05$

Test used: One way ANOVA followed by post-hoc tukey

$\mathrm{A}=\mathrm{P} 1$ : significance relative to Group 1

$\mathrm{B}=\mathrm{P} 2$ : significance relative to Group 2

$\mathrm{C}=\mathrm{P} 3$ : significance relative to Group 3

$\mathrm{D}=\mathrm{P} 4$ : significance relative to Group 4

Table 3: Showing the mean area $\%$ and SD of for PCNA among all groups with comparison between all groups by Post Hoc tukey test

\begin{tabular}{|c|c|c|c|c|c|c|c|}
\hline & & \multicolumn{6}{|c|}{ GROUPS } \\
\hline & & Group I & Group II & Group III & Group IV & Group V & $P$ \\
\hline \multirow{7}{*}{ PCNA } & Mean & 24.40 & 0.4860 & 6.844 & 19.42 & 20.45 & $<0.001^{*}$ \\
\hline & $\pm \mathrm{SD}$ & 4.479 & 0.0972 & 1.169 & 5.484 & 6.890 & \\
\hline & & & $\mathrm{P} 1=<0.001 *$ & $\mathrm{P} 1=<0.001 *$ & $\mathrm{P} 1=0.1$ & $\mathrm{P} 1=0.29$ & \\
\hline & & & & $\mathrm{P} 2=0.02 *$ & $\mathrm{P} 2=<0.001^{*}$ & $\mathrm{P} 2=<0.001 *$ & \\
\hline & Posthoc & & & & $\mathrm{P} 3=<0.001 *$ & $\mathrm{P} 3=<0.001 *$ & \\
\hline & & & & & & $\mathrm{P} 4=0.98$ & \\
\hline & & & A & A,B & $\mathrm{B}, \mathrm{C}$ & $\mathrm{B}, \mathrm{C}$ & \\
\hline
\end{tabular}

SD: standard deviation P:Probability $*$ :significance $<0.05$

Test used: One way ANOVA followed by post-hoc tukey

$\mathrm{A}=\mathrm{P} 1$ : significance relative to Group 1

$\mathrm{B}=\mathrm{P} 2$ : significance relative to Group 2

$\mathrm{C}=\mathrm{P} 3$ : significance relative to Group 3

$\mathrm{D}=\mathrm{P} 4$ : significance relative to Group 


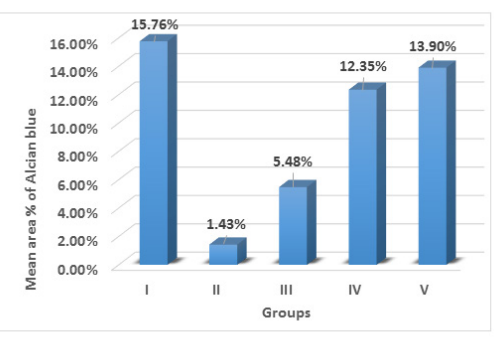

Histogram 1: The mean area\% of alcian blue-stained positive goblet cells in groups I, II, III, IV and V.

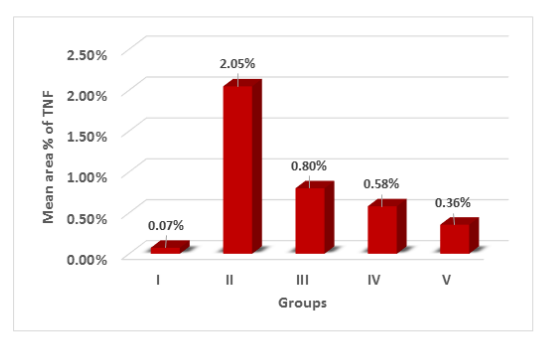

Histogram 2: The mean area \% of immuno-expression of TNF- $\alpha$ reaction in groups I, II, III, IV and V.

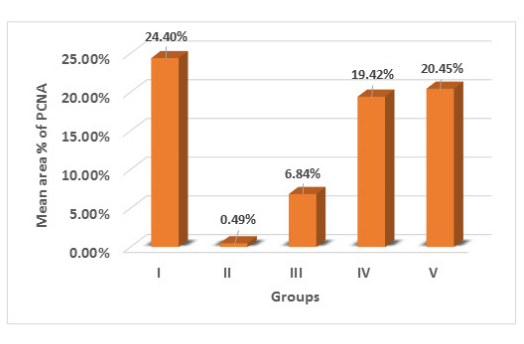

Histogram 3: The mean area\% of for immuno-expression of PCNA reaction in groups I, II, III, IV and V.

\section{DISCUSSION}

Ulcerative colitis is an idiopathic chronic and relapsing disorder that influence gastrointestinal tract ${ }^{[26]}$. Although, its pathogenesis stay unwell understood, the immune system of intestinal mucosa acts a vital role in the pathogenesis of Colitis ${ }^{[27]}$. Numerous factors, involving environmental, genetic, infectious and immune factors provoke the disease $^{[28]}$. The existing treatments for UC generally involve steroids, immune-modulating agents, anti-tumor necrosis factor, anti-interferon antibodies and anti- $\alpha$-integrin drugs. However, symptoms of ulcerative colitis cannot be totally treated ${ }^{[29]}$.Therefore, there is a critical necessity to obtain another method for UC treatment.
Ulcerative colitis was experimentally provoked in the current study by transrectal instillation of acetic acid $(5 \% \mathrm{v} / \mathrm{v})$, similar to the procedure agreed by another author ${ }^{[30]}$ who used acetic acid to stimulate an experimental example of UC

The UC group (group II) in the current experiment exhibited ulceration, damaged crypts with widespread neutrophil infiltration and congested blood vessels. Also, Statistically, this was established by significant decrease in the mean area $\%$ of alcian blue stained goblet cells when compared with (group I), significant increase in the area\% of TNF- $\alpha$ expression when compared to control group and significant decrease in area $\%$ of the immunopositive nuclei for PCNA reaction compared to (group I). This was corresponded with some authors ${ }^{[31]}$ who exhibited few goblet cells in the mucosa. Those authors ${ }^{[32,33]}$ assured there was significant rise of TNF- $\alpha$ expression in colitis group compared with treated group and with ${ }^{[34]}$ who showed prominent decrease in PCNA immunepositive nuclei in colitis group than control group.

Acetic acid is is a usual model for studying of ulcerative colitis. It enhance oxidation and lipid peroxidation and free radicals accumulation in colonic mucosa. Lipid peroxidation is a hallmark of free radical provoked tissue destruction $^{[35]}$. Also, reorganisation of unsaturated fatty acids of the membrane trigger damage of lipid membrane ending into tissue impairment, this was illustrated by authors of this study ${ }^{[36]}$. This produce localized inflammation and loss of mucosal integrity producing ulcer development ${ }^{[37]}$.

(Group III) (UC and Rebamipide) in the current study showed areas with mucosal distortion and other areas with integral mucosa. This was confirmed by significant decrease in the mean \% area of alcian blue +ve goblet cells when compared to control group. Also, there was significant increase in the $\%$ area of $\mathrm{TNF}-\alpha$ expression when compared to control group and significant decrease in the $\%$ area of expression of PCNA positive cells in (group III) compared to (group I). This was in agreement with ${ }^{[7]}$ who expressed healed mucosa of colon after treatment by rebamipide and other scientists ${ }^{[38]}$ who, said that, treatment of colitis group with rebamipide illustrated increase in goblet cells and mucin discharged by goblet cells, form a thick mucus gel layer over lying mucosa. The authors of this study ${ }^{[39]}$ demonstrated the ability of rebamipide to treat ulcerative colitis and decrease expression of TNF- $\alpha$ reaction in colonic tissue. In agreement with these findings, some scientists ${ }^{[40]}$ reported there was intestinal ulceration, that was treated by rebamipide and showed an increase of PCNA immune positive cells.

The role of rebamipide enema to treat ulcerative colitis has been described by some scientists ${ }^{[41]}$. Rebamipide control the release of free radicals, such as hydroxyl radicals and superoxide ions, as described by some authors ${ }^{[42]}$. Also, rebamipide preserve mucosa of colon integral through diminishing the permeability of the mucosa in gastrointestinal tract. It has an active role in adjustment 
of tight junction proteins of mucosa, which preserve integrity of mucosa as described by some authors ${ }^{[43]}$. All these mechanisms make rebamipide an effective drug for treating ulcerative colitis.

Mesenchymal stem cells are characterized by selfrenewal capacity and high ability of differentiation ${ }^{[44]}$. BMSCs have ability to motivate healing and dampen down inflammation. Now, it is broadly accepted that stem cells exert their therapeutic, immunomodulatory and regenerative procedures through, paracrine mechanisms including soluble molecules and extracellular vesicles. Extracellular vesicles, include exosomes and microvesicles (MVs). MVs are discharged by numerous cells and act as key communicators among cells to transport proteins, lipids and nucleic acids ${ }^{[45]}$. Paracrine signals, Coding and noncoding RNAs are also passed in such microvesicles as reported by some scientists ${ }^{[46]}$. So, MVs present a great potential donor for regenerative medicine, Re-establishing normal construction and function of impaired tissue, through the capability of MVs to deliver molecules that enhance cell division and RNA bioactive molecules ${ }^{[47]}$.

Group IV in the existing study exhibited apparently normal mucosa and crypts. It was confirmed statistically by non-significant decrease in the mean $\%$ area of alcian blue +ve cells when compared to group I. This was in agree with those authors ${ }^{[48]}$ who demonstrate that, the groups that treated by MSC-derived microvesicles show improvement in regeneration and healing of damaged epithelium and with $^{[49]}$ who stated that treatment of induced colitis with mesenchymal stem cells show numerous alcian blue positive cells. Also, there was significant decrease in \% area of TNF- $\alpha$ expression compared to group II.The result of TNF- $\alpha$ in present was coincided with authors of this study ${ }^{[50]}$ who approved decrease of TNF- $\alpha$ in group treated with microvesicles tnan colitis group. In the present study, there was increase PCNA immunopositive nuclei which agreed with the observations made by some authors ${ }^{[51]}$.

Group V in this study showed more correction in form of intact constant surface epithelium and intact regularly organized crypts with numerous goblet cells. It was confirmed statistically by non-significant decrease in the mean $\%$ area of alcian blue +ve goblet cells when compared with group I and significant increase when compared to group $\Pi$. The area $\%$ of TNF- $\alpha$ expression in group $\mathrm{V}$ was non significantly increased compared to group I, significantly increased compared to group $\Pi$ and there was non-significant decrease in the \% area of PCNA immunopositive nuclei compared to group I and significant increase in the \% area of PCNA immunopositive nuclei compared to group II.

In conclusion, each of rebamipide and microvesicle improved the prompted ulcerative colitis, but their combination was more effective.

\section{CONFLICTS OF INTEREST}

There are no conflicts of interest.

\section{REFERANCE}

1. Al-gholam MA, Mansour FK, Abdel-Fattah NA, Nooh HZ. Effect of pentoxifylline on experimental-dextran sulphate sodiuminduced colitis in rats. British Journal of Medicine \& Medical Research 2014; 4(10): 2037-2057.

2. Kunde S, Pham A, Bonczyk S, Teri C, Duba, M. Safety, tolerability, and clinical response after fecal transplantation in children and young adults with ulcerative colitis. J Pediatr Gastroenterol Nut 2013; 56:597-601.

3. Boussenna A, Cholet J, Goncalves-Mendes N, Joubert-Zakeyh J, Fraisse D, Vasson MP, Texier $\mathrm{O}$, Felgines C. Polyphenol-rich grape pomace extracts protect against dextran sulfate sodiuminduced colitis in rats. J Sci Food Agric 2016; 96 (4):1260-1268.

4. Harbord M, Rami E, Bettenworth D, Karmiris K, Katsanos K, Kopylov U, Kucharzik T, Molnar T, Raine T, Sebastian S, de Sousa HT, Dignass A, Carbonnel F. Third European Evidence-based Consensus on Diagnosis and Management of Ulcerative Colitis. Part 2: Current Management. J. Crohns Colitis 2017; 11(7):769-784

5. Panés J, García-Olmo D, Van Assche G, Colombel JF, Reinisch W, Baumgart DC, Dignass A, Nachury M, Ferrante M, Kazemi-Shirazi L. Expanded allogeneic adipose-derived mesenchymal stem cells (Cx601) for complex perianal fistulas in Crohn's disease: A phase 3 randomised, double-blind controlled trial. Lancet 2016; 388, 1281-1290.

6. Jauregui-Amezaga A, Rovira M, Marín P, Salas A, Pinó-Donnay S, Feu F, Elizalde JI, Fernández-Avilés F, Martínez C, Gutiérrez G. (): Improving safety of autologous haematopoietic stem cell transplantation in patients with Crohn's disease. Gut 2016; 9, 1456-1462.

7. Yakovenko EP, Agafonova NA, Ivanov AN, Yakovenko AV, Aldiyarova MA, Volosheinikova TV, Grigoryeva YV, Soluyanova IP. The cytoprotective drug rebamipide in therapy for inflammatory and erosive-ulcerative lesions of the gastrointestinal tract Terapevticheskii Arkhiv. 2016; 88(4):88-92.

8. Makiyama K, Takeshima F, Hamamoto T. Efficacy of rebamipide enemas in active distal ulcerative colitis and proctitis: a prospective study report. Digestive Diseases and Sciences 2005; 50 (12): 2323-2329

9. Gweon TG, Park JH, Kim BW, Choi YK, Kim JS, Park SM, Kim CW, Kim H, Chung JW. Additive Effects of Rebamipide Plus Proton Pump Inhibitors on the Expression of Tight Junction Proteins in a Rat Model of Gastro-Esophageal Reflux Disease. Gut and Liver 2018; 12(1):46-50. 
10. Wu Y, Ren M, Yang R, Liang X, Ma Y, Tang Y. Reduced immunomodulation potential of bone marrow-derived mesenchymal stem cells induced CCR4 + CCR6 + Th/Treg cell subset imbalance in ankylosing spondylitis. . Arthritis Research \& Therapy 2011. 13(1): R29.

11. Xueyi L, Lina C, Zhenbiao W, Qing H, Qiang L, Zhu P. Levels of circulating Th17 cells and regulatory $\mathrm{T}$ cells in ankylosing spondylitis patients with an inadequate response to anti-TNF-alpha therapy. J Clin Immunol 2013; 33:151-61.

12. Moon SJ, Park JS, Woo YJ, Lim MA, Kim SM, Lee SY, Kim EK, Lee HJ, Lee WS, Park SH, Jeong JH, Park SH, Kim HY, Cho ML, Min JK. Rebamipide suppresses collagen-induced arthritis through reciprocal regulation of th17/treg cell diferentiation and heme oxygenase 1 induction. Arthritis and Rheumatology 2014; 66(4):874-85.

13. Volarevic V, Arsenijevic N, Lukic ML, Stojkovic M. (): Concise review: Mesenchymal stem cell treatment of the complications of diabetes mellitus. Stem Cells 2011 ; 29: 5-10

14. El-Azab NE, Mansy A, El-Mahalaway AM, Sabry D. Comparative study of the therapeutic effect of pomegranate alone or in combinationwith bone marrow mesenchymal stem cells on experimentally induced gastric ulcer in adult male rats. Histological and immunohistochemical study. Egyptian Journal of Histology 2018; 41 (2): 150-166

15. Quesenberry PJ, Goldberg LR, Aliotta JM, Dooner MS, Pereira MG, Wen S, Camussi G. Cellular phenotype and extracellular vesicles: basic and clinical considerations. Stem Cells Dev 2014; 23 (13): 1429-1436.

16. Spees JL, Lee RH, Gregory CA. Mechanisms of mesenchymal stem/stromal cell function. Stem Cell Research \& Therapy 2016; 7 (125):1-13.

17. Sayed AA, EL-Deek SEM, EL-Baz MA, Sabry D, Rageaey A, Mansy A, Meligy FY, Abdelaziz k.(): Exosomes Derived from Bone Marrow Mesenchymal Stem Cells Restore Cisplatin Induced Ovarian Damage by Promoting Stem Cell Survival, Meiotic, and Apoptotic Marker. Global Advanced Research Journal of Medicine and Medical Sciences 2017; 6 (6):116-130.

18. EL-gowelli HM, Saad EI, Abdel-Galil AA, Ibrahim ER. Co-administration of $\alpha$-lipoic acid and cyclosporine aggravates colon ulceration of acetic acid-induced ulcerative colitis via facilitation of NO/COX-2/miR-210 cascade 2015. 288(3): 300-312.

19. Liu CJ, Jin JD, Lv TD, Wu ZZ, Ha XQ. Keratinocyte growth factor gene therapy ameliorates ulcerative colitis in rats. World Journal of Gastroenterology2011; 17(21):2632-2640.

20. Nakashima T, Maeda T, Nagamoto T, Takeshi K, Takai M, Mori T. Rebamipide Enema is Effective for Treatment of Experimental Dextran Sulfate Sodium Induced Colitis in Rats Digestive Diseases and Sciences 2005. (50) pp S124-S131

21. Bruno S, Grange C, Deregibus MC, Calogero RA, Saviozzi S, Collino F, Morando L, Busca A, Falda M, Bussolati B, Tetta C, Camussi G.: Mesenchymal stem cell-derived microvesicles protect against acute tubular injury. J. Am. Soc. Nephrol 2009; 20 (5): 1053-1067.

22. Bancroft JD, Layton C. The haematoxyline and eosin. In: Suvarna, S.K.; Layton, C. and Bancroft, J.D. Eds. Bancroft's theory \& practice of histological Techniques. 7th ed., ch. 10, Churchill Livingstone, Elsevier, Philadelphia 2013; pp 172-186.

23. Jackson P, Blythe D. Immunohistochemical techniques. In: Suvarna, S.K.; Layton, C. and Bancroft, J.D. Eds. Bancroft's theory \& practice of histological techniques. 7th ed., ch. 18, Churchill Livingstone, Elsevier, Philadelphia 2013; pp 381-426.

24. Reis LA, Borges FT, Simo es MJ, Borge AA, Sinigaglia CR, Schor N. (): Bone marrow-derived mesenchymal stem cells repaired but did not prevent gentamicin-Induced acute kidney Injury through paracrine effects in rats. PLoS One 2012; 7(9): 1-11.

25. Momen-Heravi F, Balaj L, Alian S, Trachtenberg AJ, Hochberg FH, Skog J, Kuo WP. (): Impact of biofluid viscosity on size and sedimentation efficiency of the isolated microvesicles. Front Physiol 2012; 3 (162): 1-6.

26. Salaga M, Zatorski H, Sobczak M, Chen $C$ and Fichna J. Chinese herbal medicines in the treatment of IBD and colorectal cancer: a re-view. Curr Treat Options Oncol 2014; 15: 405-420.

27. Goncalves P, Araujo JR, Di Santo JP. A Cross-talk between microbiota-derived short-chain fatty acids and the host mucosal im- mune system regulates intestinal homeostasis and inflammatory bowel disease. Inflamm Bowel Dis 2018; 24: 558-572.

28. Barnes EL, Kappelman, MD. Editorial: in-creasing incidence of pediatric inflammatory bowel disease in france: implications for etiol-ogy, diagnosis, prognosis, and treatment. Am J Gastroenterol 2018; 113: 273-275.

29. Uranga JA, Lopez-Miranda V, Lombo F and Ab-alo R. Food, nutrients and nutraceuticals af-fecting the course of inflammatory bowel disease. Pharmacol Rep 2016; 68: 816-826. 
30. Sharma H, Chauhan S, Singh PP, Raj KG. The role of antioxidants and free radicals in the healing effects of Bacopa monniera on acetic acid-induced colitis in rats. IJBCP International Journal of Basic \& Clinical Pharmacology 2017; 6(10):2388-2394.

31. El-Azab NE, Salem MY, Abd El-Salam S. A histological and immunohistochemical study of different therapeutic modalities for experimentally induced ulcerative colitis in rats.Egyptian Journal of Histology 2016; 39: pp.12-24.

32. Yue B, Ren YJ, Zhang JJ, Luo XP, Yu ZL, Ren GY, Sun AN, Deng C, Wang ZT, Dou W. Anti-Inflammatory Effects of Fargesin on Chemically Induced Inflammatory Bowel Disease in Mice. Molecules 2018; 23(6), 1380.

33. Dolatabadi F, Abdolghaffari AH, Farzaei $\mathrm{MH}$, Baeeri M, Ziarani, FS, Eslami M, Abdollahi M, Rahimi R. ():The Protective Effect of Melissa officinalis L. in Visceral Hypersensitivity in Rat Using 2 Models of Acid-induced Colitis and Stress-induced Irritable Bowel Syndrome: A Possible Role of Nitric Oxide Pathway. Neurogastroenterol Motil 2018; 24(3):490-501.

34. Deng F, Peng 1, Li Z, Tan G, Liang E, Chen S, Zhao $\mathrm{X}$, Zhi f. YAP triggers the Wnt/ $\beta$-catenin signaling pathway and promotes enterocyte self- renewal, regeneration and tumorigenesis after DSS-induced injury. Cell Death and Disease 2018; (2)9:153 (16 pages)

35. Al-Rejaie SS, Abuohashish HM, Al-Enazi MM, Al-Assaf AH, Parmar MY, Ahmed MM. Protective effect of naringenin on acetic acid-induced ulcerative colitis in rats. World J Gastroenterol 2013; (19):5633-5644.

36. D'Odorico A, Bortolan S, Cardin R, D'Inca R, Martines D, Ferronato A, Sturniolo GC. Reduced plasma antioxidant concentrations and increased oxidative DNA damage in inflammatory bowel disease. Scand J Gastroenterology2001; 36(12):1289 -94.

37. Kandhare AD, Raygude KS, Ghosh P, Ghule AE, Gosavi TP, Badole SL.Effect of hydro alcoholic extract of Hibiscus rosa sinensis Linn leaves in experimental colitis in rats. Asian Pac J Trop Biomed2012; 2 (5):337- 44.

38. Jang H, Park S, Lee J, Myung JK, Jang WS, Lee SJ, Myung H, Lee C, Kim H, Lee SS, Jin YW, Shim S. Rebamipide alleviates radiationinduced colitis through improvement of goblet cell differentiation in mice. J Gastroenterol Hepatol. 2018; 33 (4):878-886.

39. Min Hk, Kim JK, Lee SY, Kim EK, Lee SH, Lee J, Kwok SK, Cho ML, Park SH.. Rebamipide prevents peripheral arthritis and intestinal inflammation by reciprocally regulating Th17/Treg cell imbalance in mice with curdlaninduced spondyloarthritis. Journal of Translation Medicine 2016;14 (1):190.

40. Lai Y, Zhong W, Yu T, Xia Z, Li J, Ouyang H, Shan T, Yang H, Chen Q. (): Rebamipide Promotes the Regeneration of Aspirin-Induced SmallIntestine Mucosal Injury through Accumulation of $\beta$-Catenin. PLoS ONE 2015; 10(7): e0132031.

41. Makiyama K, Takeshima F, Hamamoto $T$. Efficacy of rebamipide enemas in active distal ulcerative colitis and proctitis: a prospective study report. Digestive Diseases and Sciences 2005; 50 (12): 2323-2329.

42. Moon SJ, Park JS, Woo YJ, Lim MA, Kim SM, Lee SY, Kim EK, Lee HJ, Lee WS, Park SH, Jeong JH, Park SH, Kim HY, Cho ML, Min JK. Rebamipide suppresses collagen-induced arthritis through reciprocal regulation of th17/treg cell diferentiation and heme oxygenase 1 induction. Arthritis and Rheumatology 2014; 66(4):874-85.

43. Gweon TG, Park JH, Kim BW, Choi YK, Kim JS, Park SM, Kim CW, Kim HG, Chung JW. Additive Effects of Rebamipide Plus Proton Pump Inhibitors on the Expression of Tight Junction Proteins in a Rat Model of Gastro-Esophageal Reflux Disease. Gut and Liver 2018; 12(1):46-50.

44. Yang Q, Jia L, Li X, Guo R, Huang Y, Zheng $\mathrm{Y}$ and $\mathrm{Li} \mathrm{W}$. Long noncoding RNAs: new players in the osteogenic differentiation of bone marrow- and adipose-derived mesenchymal stem cells. Stem Cell Rev 2018; 14: 297-308.

45. Kourembanas, S. Exosomes: vehicles of intercellular signaling, biomarkers, and vectors of cell therapy. Annu. Rev. Physiol 2015; 77: 13-27.

46. Yuan MJ, Maghsoudi T, Wang T. Exosomes Mediate the Intercellular Communication after Myocardial Infarction. Int. J. Med. Sci 2016; 13(2): 113-116.

47. Sayed AA, EL-Deek SEM, EL-Baz MA, Sabry D, Rageaey A, Mansy A, Meligy FY, Abdelaziz k. Exosomes Derived from Bone Marrow Mesenchymal Stem Cells Restore Cisplatin Induced Ovarian Damage by Promoting Stem Cell Survival, Meiotic, and Apoptotic Marker. Global Advanced Research Journal of Medicine and Medical Sciences 2017; 6 (6):116-130.

48. Sayed AA, EL-Deek SEM, EL-Baz MA, Sabry D, Rageaey A, Mansy A, Meligy FY, Abdelaziz k. Exosomes Derived from Bone Marrow Mesenchymal Stem Cells Restore Cisplatin Induced Ovarian Damage by Promoting Stem Cell Survival, Meiotic, and Apoptotic Marker. Global Advanced Research Journal of Medicine and Medical Sciences 2017; 6 (6):116-130, 
49. Fawzy SA, El-DinAbo-Elnou RK, Abd-El-Maksoud DF, Yousry MM. The Possible Role of Mesenchymal Stem Cells Therapy in the Repair of Experimentally Induced Colitis in Male Albino Rats. International Journal of Stem Cells 2013; 6(2):92-103.

50. Mao F, Wu Y, Tang X, Kang J, Zhang B, Yan Y, Qian H, Zhang X, Xu W. Exosomes Derived from Human Umbilical Cord Mesenchymal Stem Cells Relieve Inflammatory Bowel Disease in Mice. BioMed Research International 2017; (2):1102- 10(7):2026-2036.

51. Sayed AA, EL-Deek SEM, EL-Baz MA, Sabry D, Rageaey A, Mansy A, Meligy FY, Abdelaziz k. Exosomes Derived from Bone Marrow Mesenchymal Stem Cells Restore Cisplatin Induced Ovarian Damage by Promoting Stem Cell Survival, Meiotic, and Apoptotic Marker. Global Advanced Research Journal of Medicine and Medical Sciences 2017; 6 (6) :116-130. 
الملخص العربى

التاثير العلاجي المحتمل لريبامبيد والحويصلات الدقيقه المستخرجه

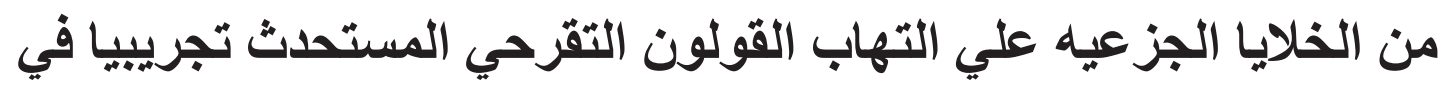

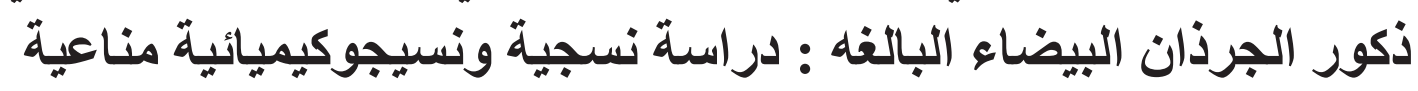

\author{
اميمه كامل هلال، عائشه السيا منسي، علا مصطقي محمد، هاله السيد احمد

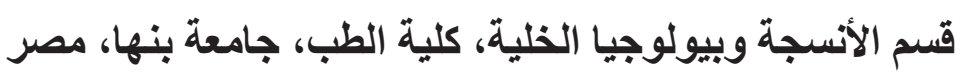

المقدمه : يعتبر التهاب القولون التقرحي من امر اض الالتهابات المزمنه ـ يتميز بوجود فترات من الألم في البطن و الإسهال الدموي. الدو اء المستخدم يحفز على تقليل الاعر اض المصاحبه ، ولكن مع وجود العديد من المضاعافات. الهدف من الدراسه : تقييم التأثنير العلاجي للريبامبيد و الحويصلات الدقيقه المستخرجه من الخلايا الجذعية الوسبطة في علاج التهاب القولون المستحث تجريبيا. الادوات والطرق: خمسين من ذكور الجرذان البالغه تم تقسيمهم إلى خمس مجمو عات: المجمو عة الأولى كانت المجمو عة الضابطة: تلقت الجرذان محلول ملحي داخل المستقيم. المجموعة الثانية: تم حقن ا الجرذان 1 مل / فأر / يوم من حمض التص الخليك 5 ٪ لمدة 3 أيام متتابعة داخل المستقيم. المجموعة الثالثة: تم إعطاء الجرذان معلق مكون من (1 ٪ ريبامبيد و 1.5 ٪ كربوكسي ميثيل السليلوز) ، عن طريق المستقيم بجر عة 1 مل / كجم بعد احداث التهاب القولون التقرحي لمدة 14 يوما. أعطيت الفئر ان من المجموعة الر ابعة جرعة واحدة من 15 ميكرو غر ام من الحويصلات الدقيقه المذابة في بهي 0.5 مل من محلول الفوسفات , تم اعطاءها عن طريق الوريد في الوريد الذيلي بعد احداث التهاب القولون التقرحي .

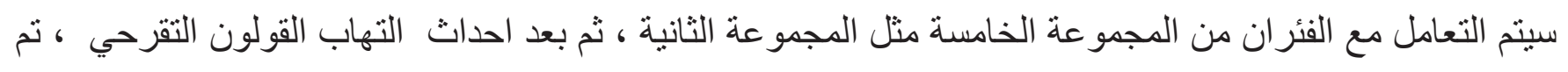
إعطاءها الريبامبيد كما في المجمو عه الثالثه و الحويصلات الدقيقه كما في المجمو عه الر ابعه. ثم تم التعامل مع عينات القولون وفحصها باستخدام الطرق النسيجية والنسيجو كيميائيه المناعية. النتائج: أظهرت المجموعة الثانية تقرح وتسلل الخلايا المتعادله في الجريبات , بالإضافة إلى إحتقان فى الاوعية الدموية. وأظهرت المجموعة الثالثة بطانة طلائية سطحية سليمة جزئيا مع فقدان مناطق أخرى من السطح. أظهرت المجمو عة الر ابعة ان الغثاء المخاطي معظمه سليم. و أظهرت المجمو عة الخامسة ان الغثاء المخاطي سليم مع وجود خلايا الامتصاص السطحيه و الخلايا الكأسيه. استتتاج: كل من الريبامبيد و الحويصلات الاقيقه يحسن التهاب القولون التقرحي ، ولكن مزيجهما أكثر فعالية. 